Katarina Marinčič

Filozofska fakulteta, Univerza v Ljubljani

Slovenija

katarina.marincic@ff.uni-lj.si
UDK 929Perko G.

DOI: 10.4312/vestnik.13.11-12

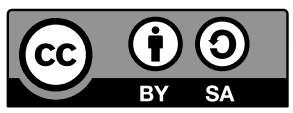

\title{
GREGORJU V SPOMIN
}

Nenadomestljiva izguba. Tako velikokrat rečemo ob smrtih, a ob Gregorjevi se zdi, da imata besedi globlji pomen. Njegova nenadomestljivost je za ljubljanske romaniste skrajno otipljiva: pogrešamo njegovo znanje in njegovo delo. Pogrešamo pa tudi manj konkretne stvari: značilni obris na hodniku; Gregorjev smisel za humor; občutek za skupnost, ki ga je izžareval.

Ko je hudo zbolel, smo sklicali krizni sestanek s študenti. Zagotovila, da bomo kljub odsotnosti profesorja Perka poskrbeli zanje, so sprejeli z vljudno skepso. Povsem očitno so bili mnenja, da jih nihče ne bo naučil toliko kot on - seveda so imeli prav. Obenem je bilo jasno videti, da jih njegova bolezen skrbi, ker ga imajo radi. Gregor je bil s svojim sijajnim, predanim pedagoškim delom dokaz, da dober profesor ni nujno strog. S prirojeno rahločutnostjo se je znal prilagoditi tako najboljšim kot tistim malo šibkejšim. Študentom je pomagal, zanje iskal poenostavitve in bližnjice. Poenostavljal je za druge, zase nikoli. V francoščini se je izpopolnjeval, ko bi že zdavnaj lahko počival na lovorikah. A je pač vedel, da zares dobre bližnjice najde le tisti, ki ima podroben pregled nad prostranstvom živega jezika. Ni bil lažno skromen - le zakaj bi bil? Bil je karizmatičen, vendar brez nastopaštva. Učil je velikodušno, ker se je zavedal svojega ogromnega znanja.

Enako trdno kot študentje smo se nanj zanašali učiteljski kolegi. Ukvarjal se je z bolonjsko prenovo, bil je predstojnik oddelka, nato prodekan. Organiziral je planinske izlete. Znal je z računalnikom. Če si ga vprašal, koliko kreditnih točk ima ta ali oni predmet v bolonjskih programih romanistike, si skoraj zagotovo dobil odgovor. Ne zato, ker bi bil po duši birokrat. Kvečjemu nasprotno: bil je tako zelo nebirokratski, da se je birokratskih opravil loteval premočrtno, brez slepilnih manevrov. In iz občutka dolžnosti, iz zavesti, da se jih nekdo pač mora.

Večina ljudi, ki smo ga poznali, se ga bo najbrž spominjala po šalah, po neusahljivi verve comique. Sama ob spominu na Gregorjeve vice vedno znova pomislim na besede, ki jih je v nekem intervjuju izrekel Gregorju tako ljubi Louis Ferdinand Céline. Smešne zgodbe - kot nasploh zgodbe - niso zastonj. Cena zanje je človeška izkušnja, ki vključuje trpljenje. Il faut payer. Et pas payer au simili, payer vraiment. Et pour l'histoire comique aussi d'ailleurs, faut payer, n'est-ce pas. 
Včasih se mi zdi, da se je Gregor šalil iz obzirnosti, da je pripovedoval vice, ker ni hotel nikogar obremenjevati s svojimi stiskami. A še bolj kot to, da je bil njegov smeh najbrž kdaj (zagotovo pa ne zmeraj!) tudi la politesse du désespoir, mi ostaja v spominu temeljna prijaznost njegovega humorja. Njegovi dovtipi niso bili nikoli zlobni, zagrenjeni ali žaljivi, blag in diskreten je bil celo v samoironiji.

V dragocenem spominu pa bom ohranila tudi nekaj kratkih, naključnih pogovorov, $\mathrm{v}$ katerih se mi je kolega, ki sem ga cenila kot jezikoslovca, nenadoma razkril kot poznavalec in strasten bralec vrhunske literature. Književnosti ni nikoli poučeval, čeprav je bil po vzporednem študiju komparativist. Najbrž je to škoda, a morda je po svoje prav. Velikansko jezikovno znanje, ki ga je tako nesebično delil, mu je prineslo tudi radosti, ki so bile samo njegove. 